\title{
PERPUTARAN ZODIAK PADA KAYON JAGAD GUMELAR SEBAGAI SIMBOL PERHITUNGAN JAWA
}

\author{
Nur Azizah ${ }^{1)}$, Dendi Pratama ${ }^{2)}$ \\ Program Studi Desain Komunikasi Visual, \\ Fakultas Bahasa dan Seni, Universitas Indraprasta PGRI \\ Jl. Nangka No. 58 C, Tanjung Barat, Jakarta Selatan, 12530, Indonesia
}

azizah289@gmail.com

\begin{abstract}
Abstrak
Dalam kehidupan orang Jawa sangat dipengaruhi oleh hal-hal yang berhubungan dengan tata cara Hindu Jawa, bahkan dari zaman dahulu yaitu zaman Hindu segala sesuatu yang berhubungan dengan kehidupan sehari-hari selalu memakai perhitungan dari sesepuh adat yang mengusai ilmu perhitungan dan masyarakat harus mematuhinya. Masyarakat melakukan ilmu perhitungan melalui pengamatan pada rasi bintang. Di Jawa dikenal dengan istilah Pawukon yang merupakan salah satu ajaran yang terdapat pada kitab primbon. Karena primbon memuat berbagai macam persoalan hidup. Pawukon merupakan rumusan perhitungan waktu, hari, bulan ataupun tahun. Pada peradaban Yunani mengenal dengan istilah zodiak yang berarti bintang yang menggambarkan 12 rasi bintang. Pada penelitian ini akan mengungkap karya Dalang dari Surakarta yaitu Bambang Suwarno yang telah menciptakan berbagai gambar simbol zodiak dalam satu kayon yang disebut Kayon Jagad Gumelar. Metode penelitian yang digunakan dalam penelitian ini adalah kualitatif. Data penelitian diambil dari studi literatur, observasi dan wawancara. Hasil penelitian ini bahwa dalam Kayon Jagad Gumelar terdapat 12 simbol yang terinspirasi dari simbol perbintangan atau disebut dengan zodiac.
\end{abstract}

Kata Kunci: kayon, zodiak, wayang

\begin{abstract}
In the life of the Javanese are strongly influenced by matters relating to the Hindu ordinances of Java, even from ancient times that the Hindu era of all things related to daily life always put on the calculations of the traditional elders that are taking the calculation of the science and society must obey. The community conducts computational sciences through observations in the constellation. In Java, it is known as Pawukon which is one of the teachings in the Book of Primbon. Because the Primbon contains various issues of life. Pawukon is a formula of time, day, month, or year calculation. The Greek civilization recognizes the zodiac term meaning a star depicting 12 constellations. This study will uncover the work of the mastermind of Surakarta, Bambang Suwarno who created various images of zodiac symbols in one kayon called Kayon Jagad Gumelar. The research methods used in this study are qualitative. Research Data is taken from literature studies, observations, and interviews. The results of this study that in Kayon Jagad Gumelar There are 12 symbols inspired by the symbols of astrology or called the Zodiac.
\end{abstract}

Keywords: wooden, zodiac, puppet

Correspondence author: Nur Azizah, azizah289@gmail.com, Jakarta, and Indonesia

c) (i)

This work is licensed under a $C C-B Y-N C$ 


\section{PENDAHULUAN}

Primbon sebenarnya sudah dikenal di berbagai Nusantara, tetapi lebih dikenal pada masyarakat Jawa, ajaran dalam primbon erat kaitannya dengan waktu. Segala sesuatu yang berhubungan dengan kehidupan sehari-hari selalu memakai perhitungan Jawa. Dalam primbon Jawa terdapat ilmu yang mempelajari waktu, hari lahir dan sifat bawaan seseorang yang biasa disebut dengan istilah pawukon.

Pawukon merupakan rumusan perhitungan waktu, baik hari, pasaran, bulan ataupun tahun (Yusuf, 2009:17). Masyarakat melakukan ilmu perhitungan melalui pengamatan pada rasi bintang. Pola rasi bintang dapat dilihat secara langsung oleh mata manusia. Pada peradaban Yunani dikenal dengan istilah zodiak yang berarti binatang dengan menggambarkan 12 rasi bintang, yaitu Aquarius, Pisces, Aries, Taurus, Gemini, Cancer, Leo, Virgo, Libra, Scorpio, Sagitarius, dan Capricon. Mengenai ramalan zodiak masih ada masyarakat yang minat dan mempercayainya yaitu Masyarakat Jawa yang biasa disebut dengan primbon.

Dalam dunia pewayangan ada gunungan wayang yang menggambarkan dua belas zodiak dalam satu gunungan, yaitu Kayon Jagad Gumelar. Di dalam gunungan ini digambarkan perputaran zodiak seperti triwikrama, yaitu tiga kali melangkah, dari tidak ada atau di dunia bawah/dunia fana menjadi ada atau di dunia tengah dan kembali tidak ada lagi atau dunia atas/akhirat.

Berdasarkan daya tarik masyarakat pada zodiak atau sebutan orang Jawa adalah primbon, maka peneliti mencoba untuk menjelaskan perputaran zodiak pada gunungan wayang gaya Surakarta yang merupakan hasil karya dari Bambang Suwarno.

\section{METODE PENELITIAN}

Metode penelitian yang digunakan adalah kualitatif dengan menggunakan beberapa teknik pengumpulan data, salah satunya langsung datang di kediaman Dr. Bambang Suwarno, S. Kar., M.Hum. Dengan metode kualitatif didapat informasi secara langsung tentang makna simbol gunungan wayang atau "kayon" gaya Surakarta sebagai zodiak Jawa. Informasi yang didapatkan dapat membantu penelitian untuk memberikan informasi kepada masyarakat tentang simbol zodiak yang ada dalam Kayon Jagad Gumelar. Data penelitian diambil dari studi literatur, observasi dan wawancara.

1. Studi literatur

Metode studi literatur ini menggunakan metode pengumpulan data dengan menggunakan beberapa referensi jurnal, skripsi dan tesis.

2. Observasi

Observasi dilakukan di Sanggar Tari Mustika Jl. Sungai Musi 34 RT 03/XIII, Demangan Sangkrah. Solo 57119. Dengan melakukan pengamatan secara langsung bentuk gunungan wayang gaya Surakarta. Dan menganalisis apa maksud dari simbol zodiak yang terdalam dalam gunungan wayang tersebut.

3. Wawancara

Wawancara dilakukan oleh peneliti kepada narasumber yang ahli dan sesuai bidang seni pewayangan, yaitu wawancara dengan Dr. Bambang Suwarno, S.Kar., M.Hum selaku Bupati Sepuh Kraton Surakarta dan Bupati Anom di Mangkunegaran. Tujuan dari wawancara untuk memperoleh informasi tentang gunungan Wayang Kulit Purwa Gaya Surakarta.

\section{HASIL DAN PEMBAHASAN Primbon}

Primbon merupakan buku yang berisi perhitungan, perkiraan, ramalan, dan sejenisnya mengenai hari baik dan hari buruk untuk melakukan kegiatan segala sesuatu, serta perhitungan untuk mengetahui nasib dan watak pribadi sesorang berdasarkan hari kelahiran, nama dan ciriciri fisik. (Yusuf: 2009). Di dalam primbon terdapat ajaran yang membahas tentang pawukon, pranata mangsa, petungan, wirid, pengobatan, aji-aji, kidung, ramalan, tata cara slametan, donga, dan ngalamat. primbon dianggap penting karena segala sesuatu berhubungan dengan 
pedoman dan tatanan tradisi. Perhitungan Jawa yang digunakan dalam primbon menggunakan perhitungan Hijriyah.

\section{Pawukon}

Dalam primbon Jawa terdapat ilmu yang mempelajari tentang waktu, hari lahir dan sifatsifat seseorang yang biasa disebut dengan istilah pawukon. kegunaan dari pawukon ini ada dua yaitu yang pertama untuk melihat hari baik untuk kemenangan dalam berperang, kedua untuk meneliti sifat, watak dan untung rugi berdasarkan hari lahir seseorang. Menurut kepercayaan tradisonal adat Jawa semua hari memiliki makna khusus dan seorang pelindung dalam bentuk pewayangan digambarkan dengan sebutan wuku. Dalam penanggalan Jawa ada 30 wuku DAN setiap wuku-nya berumur satu minggu.

Daftar wuku adalah sebagai berikut:

1. Sinta mempunyai dewa pelindung Yamadipati, wuku ini memiliki sifat keras, sering beruntung

2. Landhep mempunyai dewa pelindung Mahadewa, wuku ini memiliki sifat tampan, ayu, simpatik

3. Wukir mempunyai dewa pelindung Mahayekti, wuku ini memiliki sifat optimis, sukar mengalah

4. Kurantel mempunyai dewa pelindung Langsur, wuku ini memiliki sifat boros, pemarah

5. Tolu mempunyai dewa pelindung Baju, wuku ini memiliki sifat berwibawa, pemurung

6. Gumbreg mempunyai dewa pelindung Cakra, wuku ini memiliki sifat ulet, melindungi keluarga

7. Waringalit mempunyai dewa pelindung Asmara, wuku ini memiliki sifat simpatik, gampang atau mudah dihasut

8. Wariageng mempunyai dewa pelindung Mahayekti, wuku ini memiliki sifat ambisius, pintar bicara

9. Julungwangi mempunyai dewa pelindung Sambu, wuku ini memiliki sombong, suka cari muka

10. Sungsang mempunyai dewa pelindung Gana, wuku ini memiliki sifat pesimis, gampang rezeki

11. Galungan mempunyai dewa pelindung Kamajaya, wuku ini memiliki sifat rajin bekerja, suka iri

12. Kuningan mempunyai dewa pelindung Endra, wuku ini memiliki sifat cerdas, kreatif, pesimis

13. Langkir mempunyai dewa pelindung Kala, wuku ini memiliki sifat pemarah, tajam firasatnya

14. Mandasia mempunyai dewa pelindung Brama, wuku ini memiliki sifat berwibawa, ulet, pendendam

15. Julungpujut mempunyai dewa pelindung Guritna, wuku ini memiliki sifat simpatik, suka memerintah

16. Pahang mempunyai dewa pelindung Tantra, wuku ini memiliki sifat setia, kurang sabar

17. Kuruwelut mempunyai dewa pelindung Wisnu, wuku ini memiliki sifat banyak akal, cerdas

18. Marakeh mempunyai dewa pelindung Surenggana, wuku ini memiliki sifat rajin, kurang beruntung

19. Tambir mempunyai dewa pelindung Siwah, wuku ini memiliki sifat pintar bicara, munafik

20. Madangkungan mempunyai dewa pelindung Basuki, wuku ini memiliki sifat hemat, pemurung

21. Maktal mempunyai dewa pelindung Sakti, wuku ini memiliki sifat simpatik, kreatif, ulet

22. Wuye mempunyai dewa pelindung Kuwera, wuku ini memiliki sifat simpatik, mudah putus asa

23. Manahil mempunyai dewa pelindung Citragata, wuku ini memiliki sifat waspada, cermat, sombong

24. Prangbakat mempunyai dewa pelindung Bisma, wuku ini memiliki sifat cekatan, tegas, pemalu 
25. Bala mempunyai dewa pelindung Dewi Durga, wuku ini memiliki sifat suka bikin ribut, jahil 26. Wugu mempunyai dewa pelindung Singaljama, wuku ini memiliki sifat banyak akal, suka iri 27. Wayang mempunyai dewa pelindung Dewi Sri, wuku ini memiliki sifat simpatik,

28. Kulawu mempunyai dewa pelindung Sadana, wuku ini memiliki sifat beruntung

29. Dukut mempunyai dewa pelindung Sakri, wuku ini memiiki sifat simpatik, ulet

30. Watugunung mempunyai dewa pelindung Antaboga, wuku ini memiliki sifat religius, pemurung, waspada

\section{Kayon Jagad Gumelar}

Kayon ini pertama kali dibuat oleh Bambang Suwarno dalang dari Surakarta. Kayon Jagad Gumelar terinspirasi dari simbol perbintangan, berbagai macam zodiak digambar dalam kayon ini. Kayon ini hasil dari kerja sama dengan teater boneka di Perancis yang dipimpin oleh Alaen Recoang pada tahun 1988. Ide awalnya setiap zodiak dibuat satu persatu dalam bentuk kayon, namun setelah dipertimbangkan diputuskan untuk membuat Kayon Jagad Gumelar yang isinya simbolik zodiak, Kayon ini biasa digunakan dalam adegan pergantian pathet manyura yaitu saat tancep kayon. dalam kayon ini digambarkan perputaran zodiak seperti triwikrama yaitu tiga kali melangkah dari tidak ada menjadi ada dan kembali tidak ada lagi. Perputaran zodiac pada Kayon Jagad Gumelar ini menggunakan tiga kali langkah yang disebut dengan Triwikrama perputaran zodiak mulai dari Aries yang berada di posisi bawah yang mengartikan berada di dunia fana, kemudian ke zodiak Taurus yang berada di tengah-tengah itu menandakan dunia tengah atau alam kubur, lalu ke zodiak Gemini yang berada diatas yang menandakan dunia atas atau alam akhir.

Pada masyarakat Indonesia, setiap simbol zodiak memiliki makna dan di balik makna tersebut mempunyai fungsi yang digunakan dalam menunjang kehidupan sehari-hari. Di Jawa mengenal dengan sistem Pranata Mangsa yang merupakan aturan waktu yang digunakan petani dalam menentukan waktu suatu pekerjaan selama 365 hari. Pranata mangsa juga merupakan salah satu ajaran yang terdapat dalam kitab primbon Dalam satu tahun sistem Pranata Mangsa dibagi atas empat musim yaitu musim panas, musim dingin, musim gugur, musim semi. Kemudian terbagi atas dua belas mangsa, yang terdiri dari:

1. Mangsa Kasa (kesatu), soto murco saking embanan (mutiara lepas dari cincin pengikatnya). Masa dimana para petani membakar batang padi yang tersisa di sawah. Terdapat figur Dewa Wisnu dengan zodiak Aries

2. Mangsa karo (kedua), bantolo rengko (tanah retak) masa dimana petani mencari air untuk mengairi tumbuhannya. Terdapat figur Dewa Sambu dengan zodiak Taurus

3. Mangsa katelu (ketiga), suto manut ing bopo (anak menurut pada bapaknya). Masa dimana petani melakukan penyiraman tanaman. Terdapat figure Dewa Rudha dengan zodiak Gemini.

4. Mangsa Kapat (keempat) waspo kumembeng jroning kalbu (air mata menggenang dalam kalbu). Masa dimana petani mulai menanam, terdapat figur Dewa Yama dengan zodiak Cancer

5. Mangsa Kalima (kelima) pancuran emas sumawur ing jagad (pancuran emas menyinari dunia) masa dimana para petani mulai memperbaiki dan membuat pengairan dipinggiran sawah. Terdapat figur Dewa Metri dengan zodiak Leo.

6. Mangsa Kanem (keenam) roso mulyo kasucian (sedang banyak buah-buahan) masa dimana para petani mulai melakukan pekerjaannya disawah, banyak buah-buahan. Terdapat figur Dewa Naya dengan zodiak Virgo.

7. Mangsa Kapitu (ketuju) wiso kenter ing maruto (racun hanyut bersama angin) musim dimana ditandai dengan banjir dan angin kencang, para petani mulai menanam padi. Terdapat figur Dewa Sanghyang dengan zodiak Libra.

8. Mangsa Kawulu (kedelapan) anjrah jroning kayun (keluar isi hati). Masa dimana tanaman padi sudah tinggi, sebagian sudah berbuah. Terdapat figur Dewa Durma dengan zodiak Scorpio.

9. Mangsa Kasanga (kesembilan) wedaring wono mulyo (munculnya suara-suara mulia). Masa dimana musim padi sudah berubah. Terdapat figur Dewa Wasana dengan zodiak Sagitarius. 
10. Mangsa Kasapuluh (kesepuluh) gedhong minep jroning kayun (Gedung terperangkap dalam kalbu). Masa dimana para petani memanem padi. Terdapat figur Dewa Basuki dengan zodiak Capricon.

11. Mangsa Dhesta (kesebelas) sotyo sinoro wedi (intan yang bersinar mulia). Masa dimana petani mulai panen raya. Terdapat zodiak Aquarius Mangsa Sadha (keduabelas) tiro sag saking sasono (air meninggalkan rumahnya) masa dimana para petani mulai menjemur padi. Terdapat zodiak Pisces.

Perputaran zodiak pada Kayon Jagad Gumelar ini menggambarkan pergerakan posisi rasi bintang yang mencakup area zodiak di langit, kemudian oleh astronomi barat dikelompokan menjadi 12 zodiak sebagaimana digunakan untuk penanda waktu untuk menanam, menentukan hari baik dan hari buruk, meneliti watak dan sifat seseorang. Pada kayon jagad gumelar terdapat 12 zodiak dengan posisi penempatannya menggunakan urutan perhitungan bulan disesuaikan dengan Hijriyah kayon ini diciptakan sebagai simbol perhitungan Jawa yang dikenal dengan zodiak.

\section{SIMPULAN}

Berdasarkan pembahasan di atas, dapat disimpulkan bahwa masyarakat masih mempercayai perhitungan Jawa, kepercayaan mereka dalam perhitungan Jawa dijadikan sebagai pengontrol dalam berperilaku sehari-hari agar terhindar dari hal-hal yang tidak diinginkan. Walaupun mereka tahu bahwa hidup ini sudah diatur oleh Allah. Dalam perhitungan Jawa masyarakat mempercayai bahwa semua hari mempunyai dewa pelindung. Dalam Kayon Jagad Gumelar Terdapat 12 simbol yang terinspirasi dari simbol perbintangan yang biasa disebut dengan zodiak. Kayon ini hasil kerja sama dengan teater boneka di perancis, yang berisi simbolik zodiak yang meliputi aries, taurus, gemini, cancer, leo, virgo, libra, scorpio, sagitarius, capricon, aquarius, dan pisces. Dalam masyarakat Jawa dikenal dengan istilah primbon. Di dalam primbon sendiri terdapat ajaran yang membahas tentang pawukon, pranata mangsa, petungan, wirid, pengobatan, aji-aji, kidung, ramalan, tata cara slametan, donga, dan ngalamat. Pada Kayon Jagad Gumelar terdapat perputaran zodiak seperti triwikrama yaitu tiga kali melangkah dari tidak ada menjadi ada dan kembali tidak ada lagi. Seperti halnya dengan pathet juga terdiri dari tiga macam pathet. Simbol-simbol yang terdapat di dalam Kayon Jagad Gumelar tersusun secara rapi dan masih mengikuti aturan waktu. Pada kayon ini terdapat 12 zodiak. Kayon diciptakan sebagai simbol perhitungan Jawa yang dikenal dengan zodiak. Setiap simbol zodiaknya memiliki makna dan di balik makna tersebut mempunyai fungsi yang digunakan dalam menunjang kehidupan sehari-hari.

\section{DAFTAR PUSTAKA}

Stefani, A. $\quad$ V. (2016). Landasan konseptual perencanaan dan perancangan planetarium di Bantul. (skripsi). Fakultas Teknik, Universitas Atma Jaya, Yogyakarta

Yusuf, B. A. (2009) Konsep ruang dan waktu dalam primbon serta aplikasinya pada masyarakat Jawa. (skripsi). Fakultas Ushuluddin dan Filsafat, Universitas Islam Negeri Syarif Hidayatullah, Jakarta.

Purwoko, A. (2013). Gunungan nilai-nilai filsafat Jawa. Yogyakarta: Graha Ilmu.

Budiatmi. (2004). Inovasi kayon wayang kulit purwa karya Bambang Suwarno,kajian bentuk, ornamen, rupa, dan simbol kayon. (Tesis). Progam Studi Pengkajian Seni, Sekolah Tinggi Seni Indonesia Surakarta, Surakarta. 